\title{
THE EFFECT OF CAPITAL STRUCTURE AND GOOD CORPORATE GOVERNANCE ON FINANCIAL PERFORMANCE
}

\author{
${ }^{1}$ Putri Renalita Sutra Tanjung $\quad{ }^{1}$ Universitas Mercu Buana, Jakarta, Indonesia
}

\begin{abstract}
Article DOI URL: https://doi.org/10.36713/epra5433

This study aims to examine the effect of Capital Structure and Good Corporate Governance on Financial Performance. This research's object is the food and beverages sub-sector manufacturing companies listed on the Indonesia Stock Exchange in 2014-2018. This research was conducted using a sample of 18 selected companies listed on the Indonesia Stock Exchange. Determination of the selection using a purposive sampling method with criteria determined by the researcher using a causal relationship design. Therefore, the data analysis used is statistical analysis in the form of multiple linear regression tests. This study indicates that Debt to Asset Ratio has a significant negative effect on Financial Performance; Independent Commissioners have a significant positive on Financial Performance. At the same time, the Board of Directors and managerial ownership does not affect Financial Performance.
\end{abstract}

KEYWORDS: Capital Structure, Good Corporate Governance, Financial Performance

\section{INTRODUCTION}

In the current era of globalization, Indonesia's industrial world has made a lot of progress. One of the industries experiencing growth is the manufacturing industry, where this industry is the largest contributor to economic growth compared to other sectors; the development of the manufacturing industry mainly occurs in the food and beverage industry sub-sector. However, based on the growth chart of the food and beverage sub-sector submitted by the central statistical agency, a slowdown in growth occurred between the first quarter to the fourth quarter of 2018. The slowdown in growth in this sector was caused by restrained public consumption. The downturn in this sector's development has resulted in several declines in PT Indofood Sukses Makmur Tbk's performance. Net profit from Indofood Sukses Makmur Tbk decreased slightly by $5.7 \%$ from $5.93 \%$ in the previous year. This is due to the increase in the cost of goods sold and the company's performance expenses. The increase in the company's performance costs was due to the rise in palm oil prices, where Indofood Sukses Makmur's flagship product uses palm oil as raw material. This reduces profits and makes the financial performance of PT Indofood Sukses Makmur Tbk considered less than optimal.

One indicator that shows that a company successfully manages its resources in assessing the company's financial performance. Financial performance is an achievement that the company has achieved and is stated in a company's financial report for a certain period (Fadillah, 2017). The profitability ratio is a financial ratio used as the basis for 
measuring economic performance by investors; the profitability ratio commonly used in measurement is Return On Asset (ROA) because ROA can show how much its ability to use its assets efficiently to generate maximum profit. (Kristianti, 2018).

The capital structure is a description of its financial form, namely between its capital, which is the source of company funding, and fortune that comes from long-term debt (Fahmi, 2014: 175). The capital structure can help investors assess the level of risk and rate of return that will be received. In a capital structure study on financial performance, Aziz and Hartono (2017) show that capital structure harms financial performance. Meanwhile, research conducted by Aini et al. (2017) shows different results, namely that it does not affect economic performance.

Apart from capital structure, Good Corporate Governance is also able to influence the company's financial performance. Corporate governance is used to create transparent company management for users of financial reports; if this concept is appropriately implemented, company management's transparency will also continue to improve (Pakpahan et al., 2017). There are several indicators in implementing good corporate governance, including the board of directors, independent commissioners, and managerial ownership.

According to POJK, No.33 / POJK.04 / 2014 is a company organ that has full authority and responsibility for its management and the benefit of the company. According to research conducted by Setiawan (2016), the board of directors does not affect the company's financial performance. Meanwhile, according to Putri and Muid (2017), Chairunesia, Sutra, and Wahyudi (2018), it shows that the board of directors positively affects financial performance. An independent commissioner is a commissioner with no affiliation or business relationship with members of the board of commissioners, the board of directors, and shareholders with a controlling level (Azis and Hartono, 2017). According to research by Sarafina and Saifi (2017), it shows that independent commissioners have a positive effect on financial performance. Meanwhile, according to Wardani and Zulkifli (2017), it shows that independent commissioners do not affect economic performance. Managerial ownership is shares owned by company management (Hermiyetti and Katlanis, 2016). Research conducted by Larasati et al. (2017) shows that managerial ownership affects financial performance. Meanwhile, according to Aprianingsih (2016), managerial ownership does not involve financial performance..

\section{LITERATURE REVIEW Agency Theory}

According to Jensen and Meckling (1976), an agency relationship is a contract between the owner (principal) who uses the services of another person (agent) to perform services on behalf of the owner, including delegation of authority and decision-making relating to the company. The agent/manager certainly better knows internal information and its prospects as the company manager than the owner (principal). This often triggers a conflict between the principal and the agent. To minimize friction, companies can implement good corporate governance as a monitoring material and increase debt levels. With this application, it is hoped that the agent can act by the owner's wishes; namely, the increasing company returns so that company performance increases (Tertius and Christiawan, 2015).

\section{Financial Performance}

Financial performance is a description of the company's condition in a certain period related to the aspects of raising funds and channeling funds, as measured by indicators of liquidity and profitability (Jumingan, 2014: 239). Return on assets (ROA) is part of the profitability ratio, which is a ratio that measures the company's ability to generate profits using its assets. The ROA value can indicate the level of management effectiveness in using company assets to create profits. The higher the ROA value, the better the company's financial performance (Kristianti, 2018). Return On Asset can be formulated as follows (Brigham, Eugene, \& Houston, 2014: 148):

$$
R O A=\frac{\text { Net income }}{\text { Total Assets }}
$$

\section{Capital Structure}

Capital structure is a description of its financial form, namely between its capital, which is the source of company funding, and prosperity that comes from long-term debt (Fahmi, 2014: 175). The capital structure in this study is proxied by the Debt to Asset Ratio (DAR). DAR is a part of the leverage ratio. Debt to Asset Ratio is used to measure how much the company's assets are financed by debt. Debt to Asset Ratio can be formulated as follows (Fahmi, 2014: 75):

$$
D A R=\frac{\text { Total Liabilities }}{\text { Total Assets }}
$$

\section{Good Corporate Governance}

Good Corporate Governance (GCG) is a form of management a good company, which includes protecting shareholders' interests as company owners and creditors as funders (Setianingsih et al., 2014). According to Saifi (2019), in implementing Corporate Governance, there are several principles that companies need to apply to serve as company guidelines in running their business, namely accountability, transparency, responsibility, independence, and fairness. In assessing good corporate governance, it can be done through several indicators such as the board of 
directors, independent commissioners, and managerial ownership.

1. Board of Directors. According to the Financial Services Authority Regulation No.33 / POJK.04 / 2014, the board of directors is an organ of the issuer or public company that has full authority and responsibility for the management of the issuer or public company for the benefit of the issuer or public company, by the intent and purpose of the issuer or company. Public and represent the issuer or public company, both inside and outside the court, by the provisions of the articles of association. The board of directors' task is to determine the direction and strategy of the company's resources in the short and long term. The formula for calculating the board of directors is as follows (Addiyah and Chairiri, 2014):

\section{Board of Directors $=$}

\section{$\Sigma$ Members of the Board of Directors}

2. Independent Commissioner. According to the Financial Services Authority Regulation No.33 / POJK.04 / 2014, an independent commissioner is a member of the board of commissioners from outside the issuer or public company and meets the requirements as an independent commissioner as referred to in this financial services authority regulation. Independent commissioners can have a positive effect on the company because the independent board of commissioners provides a variety of perspectives that can increase the potential for the work environment and better solutions in dealing with problems within the company so that they can help improve the company performance (Azis and Hartono, 2017). The calculation formula for independent commissioners is as follows (Oemar, 2014):

$$
\text { Independent Commissioner }=\frac{\sum \text { Independent Commissioner }}{\sum \text { the entire board of commissioners }} \times 100 \%
$$

3. Managerial ownership. Managerial ownership is the total shares owned by the management (manager). Managerial share ownership can help unify interests between shareholders and managers (Hermiyetti and Katlanis, 2016). The higher the proportion of managerial share ownership, the better the company's performance. The formula for calculating managerial ownership is as follows (Gurdyanto et al., 2019).

$$
\text { Managerial ownership }=\frac{\sum \text { Shares Owned By Management }}{\sum \text { Outstanding Shares }} \times 100 \%
$$

\section{Past Research}

Research conducted by Agustina and Santosa (2019) The effect of DAR, DER, and Corporate Governance on Financial Performance provides hypothesis testing results that DAR does not affect financial performance, DER harms financial performance, Independent Commissioners break financial performance, and DAR, DER, independent commissioners simultaneously have a positive impact on the company's economic performance.

Research conducted by Ningsih, et al. (2019) The Effect of Good Corporate Governance and Ownership Structure on Company Performance. Provide the results of testing the hypothesis of independent commissioners, the board of directors, audit committee, managerial ownership, institutional ownership simultaneously have a positive effect on company performance; independent commissioners do not affect company performance, boards of directors have a positive impact on company performance, the audit committee has no effect on company performance, Managerial ownership has no impact on company performance. Institutional ownership does not affect company performance.

Research conducted by Akshita Arora and Chandan Sharma (2016) Corporate Governance and
Firm Performance in Developing Countries shows that board size harms ROA, and board meetings positively impact ROA.

Research conducted by Masitoh and Hidayah (2018) The effect of the implementation of good corporate governance on company performance resulted in the conclusion that public ownership does not affect company performance, managerial ownership does not affect company performance, board size has a positive impact on company performance, independent board of directors has a negative effect. On company performance, the independent panel of commissioners does not affect.

Research conducted by Kennedy Okiro, Josiah Aduda, and Nixon Omoro (2015) The Effect Of Good Corporate Governance And Capital Structure On Performance Of Firms Listed At The East African Community Securities Exchange shows that good corporate governance has a significant positive effect on firm performance, the capital. The structure has a significant positive impact on athletic performance.

Research conducted by Chairunesia, Sutra, and Wahyudi (2018), The Effect of Good Corporate Governance and Financial Distress on Profit Management, shows that good corporate governance 
does not affect earnings management. Meanwhile, financial distress affects earnings management.

Hidayah the effect of Investment Opportunity Set (using CAPBVA price proxy and MVBVE Investment Proxy) and managerial ownership on firm value The results of this study indicate that the independent variable is IOS (CAPBVA and MVBVE) have a significant effect on firm value, while managerial ownership variables have no significant impact on firm value.

Bintara and Tanjung. Analysis of Fundamental Factors on Stock Return, explains that Return on Assets, Current Ratio, Debt to Equity, and Price Earning Ratio affect the value of the company proxied by Stock Return. In contrast, PBV does not affect the value of the company.

Tanjung and Wahyudi. Analysis of the Effect of Disclosure of Sustainability Report, Economic Value Added, and Other Fundamental Factors of Companies on Company Value explains that Debt to Equity and Price Earning Ratio affect the firm's value.

\section{THINKING FRAMEWORK AND HYPOTHESES \\ The Effect of Capital Structure on Company Financial Performance}

Capital structure is the activity of financing the company's operations using debt or equity. Companies with high long-term debt levels increase interest on the debt and increase the risk of default. This will affect the company's profitability and financial performance (Azis and Hartono, 2017).

H1: Debt to asset ratio harms the company's financial performance
The Effect of the Board of Directors on the Company's Financial Performance

The more the number of boards of directors, the more optimal the level of supervision will be. The decision-making process will be more accurate to positively impact the company's financial performance (Lestari and Sari, 2017).

$\mathrm{H} 2$ : The board of directors has a positive effect on the company's financial performance

\section{The Effect of Independent Commissioners on the Company's Financial Performance}

Independent commissioners are thought to have a positive impact on the company because the independent board of commissioners provides a variety of views that can increase the potential of the work environment and offer more creative solutions to problems in the company so that it can help improve the company performance (Azis and Hartono, 2017).

H3: Independent commissioners have a positive effect on the company's financial performance

\section{Effect of Managerial Ownership on Company Financial Performance}

Managerial ownership can improve company performance because managers will be more motivated to double their efforts, which have a role as part of the shareholder to manage the company well to maximize its financial performance (Hermiyetti and Katlanis, 2016).

H4: Managerial ownership has a positive effect on the company's financial performance

Based on the theoretical basis and the results of previous research and the problems raised, the following is a theoretical framework outlined in the research model, as shown in the following figure:

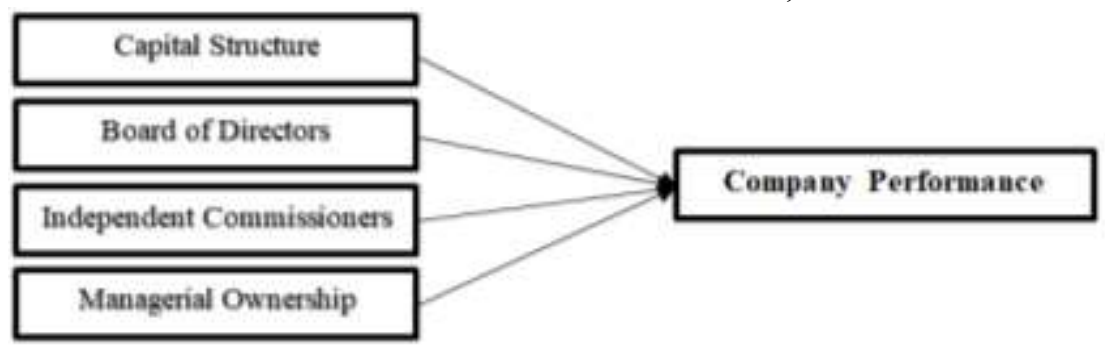

\section{METHOD}

\section{Population and Sample Research}

This study's population is the food and beverage sub-sector manufacturing companies listed on the Indonesia Stock Exchange from 2013 to 2018 that publish annual financial reports.

Sampling was done by using the purposive sampling method, which is part of the non-probability selection. Samples to be taken care of based on predetermined criteria. The sample criteria used in this study are as follows:

1. Food and beverage sub-sector manufacturing
Figure 1. Framework

companies listed on the Indonesia Stock Exchange consecutively in the 2013-2018 period

2. Food and beverage sub-sector manufacturing companies whose financial reports were not successful

3. Food and beverage sub-sector manufacturing companies that have IPO 2017-2018

\section{Data Analysis Method}

Data analysis was performed using multiple linear regression analysis, including the following calculation: 
1. Descriptive Statistical Test

2. Classical Assumption Test which consists of Normality Test, Multicollinearity Test, Heteroscedasticity Test, and Autocorrelation Test

3. Model Feasibility Test, which consists of the Analysis of the Coefficient of Determination (R2 Test), Fit Model Feasibility Test (f test), and
Partial Test (t-test).

\section{RESULTS AND DISCUSSION Descriptive statistics}

The results of data processing can be seen from the descriptive statistics below:

Table 1. Descriptive Statistics

\begin{tabular}{|l|c|c|c|c|c|}
\hline & $\mathrm{N}$ & Minimum & Maximum & Mean & Std. Deviation \\
\hline ROA & 90 &,- 2604 &, 5267 &, 067522 &, 1162715 \\
CS & 90 &, 0387 &, 9190 &, 475368 &, 1891070 \\
BOD & 90 & 2 & 10 & 4,84 & 2,114 \\
IC & 90 &, 3333 &, 5714 &, 382718 &, 0715839 \\
MO & 90 &, 0000 &, 3451 &, 029144 &, 0709599 \\
Valid N (listwise) & 90 & & & & \\
\hline
\end{tabular}

In the SSS output results above, a descriptive statistic can be seen of the capital structure, good corporate governance, and financial performance:

a. Financial performance (ROA) has the lowest (minimum) value of (-0.2604) owned by PT Magna Investama Mandiri Tbk in 2016. This is due to weak economic growth, as well as the financing sector that has not grown significantly. Thus, Magna Investama Mandiri decided to move its line of business by acquiring companies engaged in rice milling and rice management. Meanwhile, the highest value (maximum) of 0.5267 was owned by PT Multi Bintang Indonesia Tbk in 2017. This is due to the sales growth carried out by PT Multi Bintang Indonesia by increasing distribution to $10 \%$ nationally. This shows that the company's profits demonstrate profitability as a measure of company performance. The number of average (mean) Return on Assets in the company from the 90 data studied was 0.067522 .

b. Capital Structure (DAR) has the lowest (minimum) value of 0.0387 owned by PT Inti Agri Resources Tbk in 2015; this shows that the capital structure used by PT Inti Agri Resources Tbk uses more assets than debt to finance needs. His company. Meanwhile, the highest value (maximum) of 0.9190 owned by PT Magna Investama Tbk in 2018 used a more considerable debt to fund its activities. The overall average DAR value of companies in the food and beverage industry in 2014-2018 is 0.4754 units, which means that every Rp. 1 asset in the company is used to pay off the total liabilities of Rp. 0.4754. In general, it can be concluded that companies in the food and beverage industry in 2014-2018 are solvable. The company can provide guarantees against third parties, namely creditors who provide loans to the company. The average number (mean) of DAR in the companies from the 90 data studied was 0.4754 .

c. The Board of Directors has the lowest (minimum) score of 2 owned by PT Akasha Wira International Tbk in 2018, PT Inti Agri
Resources Tbk for the 2014-2018 period, PT Magna Investama Mandiri Tbk, and PT Tri Banyan Tirta for the 2017-2018 period. This is due to changes in the composition of the board of directors and cost-efficiency. With the number of board of directors of 2 people, the company can still carry out their duties and obligations so that the resulting performance is still relatively good. Meanwhile, the highest value (maximum) of 10 is owned by PT Indofood Sukses Makmur Tbk from 2015-2017. Having ten members of the board of directors can maximize the company's operational structure because of the even distribution of tasks and responsibilities.

d. Independent commissioners have the lowest (minimum) score of 0.3333 owned by PT Akasha Wira International Tbk, PT Bumi Teknokultura Tbk, PT Budi Strach and sweetener Tbk, PT Wilmar Cahaya Indonesia Tbk, PT Inti Agri Resources Tbk, PT Prasidha Aneka Niaga Tbk, PT Nippon Indosari Tbk, PT Sekar Bumi Tbk, PT Sekar Laut Tbk, PT Ultrajaya Milk \& Trading Co Tbk in 2014-2018. PT Indofood CBP Sukses Makmur Tbk in 2015, and PT Tri Banyan Tirta Tbk in 2014-2016. This shows that the performance of independent commissioners in the company is low, which is only $33.3 \%$. Meanwhile, the highest value (maximum) of 0.5714 was owned by PT Multi Bintang Indonesia Tbk in 2015 and 2016. This shows that the independent board of commissioners' performance is high, namely $57.14 \%$. The average (mean) number of independent commissioners from the 65 data studied was 0.383791 , with a standard deviation of 0.0702273 , which means that the standard deviation value is smaller than the average value (mean). This shows that the data is well distributed.

e. Managerial ownership has the lowest (minimum) value in this study of 0 ; this shows that the company's lawyers do not own shares in the company. Meanwhile, this study's maximum managerial ownership value was 0.3451 , which 
was obtained from PT Ultrajaya Milk Industry and Trading Company Tbk in 2018. This shows that the company's shares are owned by layers of managers in the company with the expectation of share ownership by the parties. Management can motivate managers to improve the company's financial performance.

\section{Classic Assumption Test}

The classic assumption test is carried out so that the regression model in the research is significant and representative. In the multiple regression analysis, it is necessary to avoid any standard assumption deviation so that problems do not arise in its use. The basic assumption is that the data is normally distributed; there is no heteroscedasticity, multicollinearity, and autocorrelation. Based on the normality test in this study, the Asymp value model. Sig. (2tailed) $=0.200$, then according to the provisions of $0.200>0.05$, the residual value is normal. Then the data in the model can be said to be normally distributed. Multicollinearity test which shows that the VIF value is below 10, and the tolerance value is above 0.10 . From the results of these tests, it can be concluded that the regression model does not have multicollinearity problems. Heterokedatisitas test shows that there was no heteroscedasticity. This can be seen from the probability of its significance (Sig. Value) on each independent variable above the $5 \%$ confidence level or 0.05 . So it can be concluded that the regression capital does not contain heteroscedasticity. The autocorrelation test in this study used the autocorrelation test using the Durbin-Watson (DW) test. The results of the autocorrelation test data obtained no positive or negative autocorrelation, or it can be concluded that there is no autocorrelation.

\section{Hypothesis Testing Results Determinant Coefficient Test Results (R2)}

According to Ghozali, the coefficient of determination essentially measures how far the model's ability to explain variations in the dependent variable. The ratio of determination aimed at $\mathrm{R}^{2}$ from the regression model is used to determine the dependent variable that can explain the magnitude of the variability of the dependent variable. The coefficient of determination test results is known that the R Square value of $21.7 \%$, this shows that the variation Company Financial Performance can be explained by changes in Capital structure, Board of Directors, Independent Commissioners, and Managerial Ownership by $21.7 \%$. While the remaining $78,3 \%(100 \%-21.7 \%)$ is solved or influenced by other factors not examined in this study.

\section{Model Feasibility Test Results (Test F)}

According to Ghozali, F statistical test is basically to show whether all independent variables are included. Based on the table above, it is known that the calculated $\mathrm{F}$ value of 16.637 with a probability of $0,000<0.05$; this indicates that the model used in this study is feasible. So in this regression model, it can be concluded that the variables of in Capital structure, Board of Directors, Independent Commissioners, and Managerial Ownershi affect the Company Financial Performance

\section{Partial Hypothesis Testing (t test)}

The $t$ test is used to determine whether the independent variable partially affects the dependent variable, with a significance level of $5 \%$. If the sig value is greater than 0.05 , then $\mathrm{H} 0$ is accepted. If the sig value is less than 0.05 then $\mathrm{HO}$ is rejected and $\mathrm{Ha}$ is accepted. The results of the T test are as follows:

Table 2. Partial Hypothesis Testing ( $t$ test)

\begin{tabular}{|l|c|c|c|c|}
\hline \multirow{2}{*}{ Model } & \multicolumn{2}{|c|}{$\begin{array}{c}\text { Unstandardized } \\
\text { Coefficients }\end{array}$} & \multirow{2}{*}{ Sig. } \\
\cline { 2 - 3 } & B & \multicolumn{1}{|c|}{ Std. Error } & & \\
\hline (Constant) &,- 155 &, 071 & $-2,187$ &, 032 \\
CS &,- 174 &, 062 & $-2,806$ &, 006 \\
1 BOD &, 009 &, 005 & 1,646 &, 103 \\
IC &, 671 &, 161 & 4,156 &, 000 \\
MO &, 179 &, 163 & 1,100 &, 275 \\
\hline
\end{tabular}

Based on the table above, the multiple linear regression equation can be obtained as follows:

$$
\mathrm{ROA}=(-0,155)+(-0,174) \mathrm{CS}+0,009 \mathrm{BOD}+0,671 \mathrm{IC}+0,179 \mathrm{MO}+e
$$

1. The Effect of Capital Structure on the Company's Financial Performance

The t-test analysis results on the table of capital structure variables measured using DAR (Debt to Asset Ratio) show that $t$ has a value of (1.248) with a significant probability of 0.217 . This indicates that the possibility of significance is greater than the significance level $\alpha=0.05$ or
$5 \%(0.217>0.05)$. So that $\mathrm{H} 1$ is rejected, this shows that the capital structure variable measured using DAR (Debt to Asset Ratio) partially does not affect the company's financial performance. This study's results are in line with the results of research conducted by Aini (2017), Jufrizen et al. (2019), which states that the capital structure measured using the Debt to 
Asset Ratio does not affect financial performance. This shows that large or small the level of debt owed by the company will not affect the company's financial performance, which is usually assessed from profit because the company will still be able to generate high profits when the level of sales increases.

2. The Effect of Directors on the Company's Financial Performance

The t-test analysis results on the table of directors' variables, which is one of the indicators of good corporate governance, shows that $t$ has a value of $(-2.476)$ with a significant probability of 0.016 . This indicates that the possibility of significance is less than the significance level $\alpha=0.05$ or $5 \%(0.016<0.05)$. So that $\mathrm{H} 2$ is accepted and rejects $\mathrm{H} 0$, this shows that the director's variable partially harms the company's financial performance.

This study's results align with Rimardhani \& Dwi Atmanto (2016), Putri, and Dul Muid (2017). The board of directors has a role as a leader who can help direct the company's implementation of strategies and policies to improve performance. However, when a company has a large number of boards of directors. This will create new conflicts, namely difficulties in uniting thoughts so that the board of directors cannot coordinate and make the right decisions in carrying out the control function, which will cause a decline in the company's financial performance.

3. The Effect of Independent Commissioners on the Company's Financial Performance

Based on the t-test analysis results on the table, the independent commissioner variable, which is one of the indicators of good corporate governance, shows that $t$ has a value of 6.154 with a significant probability of 0.000 . This indicates that the significance probability is smaller than the significance level $\alpha=0.05$ or $5 \%(0.000<0.05)$. So that H3 is accepted, this shows that the independent commissioner

\section{CONCLUSIONS AND RECOMMENDATIONS} Conclusion

From the research results in the previous chapter, the following conclusions can be drawn:

1. Capital structure (DAR) does not affect the company's financial performance.

2. The Board of Directors harms the company's financial performance

3. Independent Commissioner has a positive impact on the company's financial performance

4. Managerial ownership does not affect the company's economic performance. variable partially has a significant positive effect on the company's financial performance.

The results of this study are in line with Putra (2015), Fadillah (2017), Agustina and Awan (2019), which state that independent commissioners have a significant positive effect on financial performance. In theory, an independent commissioner can act as an intermediary in a dispute between internal managers and can oversee policies and serve as a provider of advice to the board of directors. Independent commissioners have a supervisory function over the management of the company to create a company with good governance and improve the company's financial performance.

4. The Effect of Managerial Ownership on Company Financial Performance

Based on the t-test analysis results on the table, the managerial ownership variable, which is one of the indicators of good corporate governance, shows that $t$ has a value of $(-0.333)$ with a significant probability of 0.740 . This indicates that the possibility of significance is greater than the significance level $\alpha=0.05$ or $5 \%(0.740>$ 0.05 ). So this shows that $\mathrm{H} 4$ is rejected, and $\mathrm{H} 0$ is accepted. So it can be concluded that the managerial ownership variable partially does not significantly affect the company's financial performance.

This study's results are in line with Aprianingsih (2016), Gurdyanto et al. (2019), which state that managerial Ownership does not significantly affect financial performance. Managerial Ownership is a condition where management has share ownership in a company. It has a role as the company's manager and the share owner/investor in the company. However, not all management has a high proportion of share ownership so that managers will feel less satisfied with the benefits taken from the decisions they make. In the future, it cannot unify the interests of managers and shareholders. So that the large or small level of share ownership owned by management will not affect financial performance.

\section{Recommendations}

The recommendations put forward in this study include the following:

1. From the research results, it is expected that the management of food and beverage companies can reduce debt or manage it wisely because the balance between debt and assets can affect financial performance.

2. From the research results obtained, researchers suggest that investors who will invest their funds in food \& beverage sector companies pay attention to the companies' capital structure that will be used as a place to invest. 
3. Future research is expected to use other ratios to measure the capital structure and use other indicators to measure Good Corporate Governance or use other measurements.

\section{REFERENCES}

1. Addiyah, Alina, dan Anis Chariri. 2014. Pengaruh Penerapan Corporate Governance Terhadap Kinerja Keuangan Perbankan Studi Pada Perusahaan Perbankan yang Terdaftar Di BEl Tahun 2010-2012. Diponegoro Journal of Accounting Vol. 3, No. 4.

2. Agustina, Riesta Chahya, dan Awan Santosa. 2019. Pengaruh DAR, DER, dan Tata Kelola Perusahaan Terhadap Kinerja Keuangan Perusahaan Farmasi. Jurnal Ekonomi dan Manajemen (Capital). Vol. 3, No. 1.

3. Aini, Ayu Nur, Edi B.S., dan Isnani. 2017. Pengaruh Kepemilikan Institusional, Proporsi Dewan Komisaris Independen, Komite Audit, Struktur Modal, Ukuran Perusahaan, dan Leverage Terhadap Kinerja Keuangan Studi Kasus Perusahaan Manufaktur Sektor Industri Barang Konsumsi yang Terdaftar di BEI Tahun 2011-2015. Jurnal Ekonomi Universitas Pandanaran 2017.

4. Aprianingsih, Astri. 2016. Pengaruh Penerapan Good Corporate Governance, Struktur Kepemilikan, Dan Ukuran Perusahaan Terhadap Kinerja Keuangan Perbankan. Jurnal Profita Edisi 42016

5. Aprinita, B. S. (2016). Pengaruh Good Corporate Governance Terhadap Kinerja Keuangan Pada Perusahaan Sektor Consumer Goods Yang Terdaftar Di Bursa Efek Indonesia Tahun 2012-2014. Jurnal Bisnis Dan Manajemen, 52(11).

6. Azis, Abdul, dan Ulil Hartono. 2017. Pengaruh Good Corporate Governance, Struktur Modal, Dan Leverage Terhadap Kinerja Keuangan Perusahaan Pada Sektor Pertambangan Yang Terdaftar Di BEl Tahun 20112015. Jurnal Imu Manajemen Universitas Negeri Surabaya Vol. 5 No. 3.

7. Brigham, Eugene,F., and Houston. 2014. Dasar-Dasar Manajemen Keuangan. Jakarta : Salemba Empat

8. Chairunesia, W., Sutra, P. R., \& Wahyudi, S. M. (2018). Pengaruh Good Corporate Governance Dan Financial Distress Terhadap Manajemen Laba Pada Perusahaan Indonesia Yang Masuk Dalam Asean Corporate Governance Scorecard. Jurnal Profita, 11(2), 232.

9. Fadillah, Adil Ridlo. 2017. Analisis Pengaruh Dewan Komisaris Independen, Kepemilikan Manajerial, dan Kepemilikan Institusional Terhadap Kinerja Perusahaan Yang Terdaftar Di LQ 45. Jurnal Akuntansi Vol. 12 No. 1.

10. Fahmi, Irham. 2014. Manajemen Keuangan Perusahaan dan Pasar Modal. Jakarta : Mitra Wacana Media

11. Gurdyanto, Mochammad Feries, Kartika H. T., dan Anita Wijayanti. 2019. Pengaruh Corporate Governance Terhadap Kinerja Keuangan Perusahaan Manufaktur Sektor Industri Barang Konsumsi Sub Sektor Makanan Dan Minuman Di BEl. Research Fair Unisri Vol. 3, No. 1, Januari 2019.

12. Hermiyetti, dan Erlinda Katlanis. 2016. Analisis Pengaruh Kepemilikan Manajerial, Kepemilikan Institusional, Kepemilikan Asing, Dan Komite Audit Terhadap Kinerja Keuangan Perusahaan. Media Riset Akuntansi, Vol.6 No.2 Agustus 2016.

13. Hidayah, N. (2015). Pengaruh Investment O pportunity
4. Further research is expected to add the variables used. Besides that, it can also consider measuring tools to measure the company's financial performance and using ROA, such as ROE, or other measuring instruments.

Set (Ios) Dan Kepemilikan Manajerial Terhadap Nilai Perusahaan Pada Perusahaan Property Dan Real Estat Di Bursa Efek Indonesia. Jurnal Akuntansi, 19(3), 420-432.

14. Jensen, M.C and Meckling, W.H. 1976. Theory of the Firm : Managerial Behavior, Agency Costs and $O$ wnership Structure. Journal of Financial Economics, Vol. 3, No. 4, pp.305-360.

15. Jumingan. 2014. Analisis Laporan Keuangan. Jakarta : PT Bumi Aksara

16. Kristianti, I.P. 2018. Analisis Pengaruh Struktur Modal Terhadap Kinerja Keuangan Perusahaan. Akuntansi Dewantara Vol. 2 No. 1 A pril 2018.

17. Larasati, S., Hendra Titisari, K., \& Nurlaela, S. (2017). Pengaruh Good Corporate Governance Dan Corporate Social Responsibility Terhadap Kinerja Keuangan Perusahaan Manufaktur yang Terdaftar di BEI. Seminar Nasional IENACO 2017, 579-586.

18. Oemar, Fahmi. 2014. Pengaruh Corporate Governance Dan Keputusan Pendanaan Perusahaan Terhadap Kinerja Profitabilitas Dan Implikasinya Terhadap Harga Saham Studi Empiris pada Perusahaan BUMN yang Listing di BEI tahun 20082011. Jurnal Ilmiah Ekonomi dan Bisnis Vol. 11, No. 2, September 2014: 369 - 402 ISSN: 1829 - 9822.

19. Pakpahan, Novi Y. T., Elly Rasyid, dan Fharel M.H. 2017. Pengaruh Good Corporate Governance Terhadap Kinerja Keuangan Studi kasus pada perusahaan perbankan yang terdaftar di Bursa Efek Indonesia Tahun 2012-2015. fundamental management journal online ISSN: 2540-9220 Volume:2 online No.1. 2017.

20. Peraturan Otoritas Jasa Keuangan No.33/P0JK.04/2014 Pasal 1 tentang Direksi dan D ewan Komisaris Emiten Atau Perusahaan Publik.

21. Putri, R. K, Dul Muid . (2017). Pengaruh Good Corporate Governance Terhadap Kinerja Perusahaan. Diponegoro Journal of Accounting, 6(1), 1.

22. Saifi, Muhammad. 2019. Pengaruh Corporate Governance Dan Struktur Kepemilikan Terhadap Kinerja Keuangan Perusahaan. Jurnal Profit Vol. 13 No. 2, 2019.

23. Sarafina, S., \& Saifi, M. (2017). Pengaruh Good Corporate Governance dan Kinerja Perusahaan Terhadap Nilai Perusahaan (Studi Pada Badan Usaha Milik Negara Yang Terdaftar Di Bursa Efek Indonesia Tahun 2010-2013). Jurnal Administrasi Bisnis, 50(3).

24. Setianingsih, KT. Y. P., Ananta W. T. A, dan Gede A. Y. 2014. Pengaruh Good Corporate Governance Dan Pengungkapan Corporate Social Responsibility Terhadap Kinerja Perusahaan Dan Nilai Perusahaan Studi Kasus Pada Perusahaan Manufaktur Yang Terdaftar Di BEl Periode 2010 - 2012. Journal Universitas Pendidikan Ganesha Jurusan Akuntansi SI Volume: 2 No:1 Tahun 2014.

25. Setiawan, A. (2016). Pengaruh Corporate Governance Terhadap Kinerja Keuangan Perusahaan. Jurnal SIKAP (Sistem Informasi, Keuangan, Auditing Dan Perpajakan), 1(1), 1.

26. Tanjung, P.R.S., Wahyudi, S.M. (2019). Analysis the Effect Disclosure of Sustainability Report, Economic Value Added and Other Fundamental Factors of Companies on Company Value, International Journal 
of Academic Research in Accounting, Finance and Management Sciences, 9(2): 237-249

27. Tanjung, Putri Renalita Sutra. 2020. Effect of Corporate Social Responsibility Disclosure, Good Corporate Governance Implementation, and Profitability on Corporate Value (Asean Country Study 2016-2018). Saudi Journal of Business and Management Studies. Saudi Journal of Business and Management Studies

28. Tertius, Melia Agustina dan Yulius Jogi Christiawan. 2015. Pengaruh Good Corporate Governance terhadap Kinerja Perusahaan pada Sektor Keuangan. Business Accounting Review Vol. 3, No. 1, Januari 2015: 223-232

29. Wardani, F. P., \& Zulkifli, Z. (2017). Pengaruh Good Corporate Governance Terhadap Kinerja Keuangan. Kajian Bisnis STIE Widya Wiwaha, 25(2). 